

\begin{tabular}{|c|c|}
\hline Title & $\begin{array}{l}\text { ベトナム・ハノイにおける廃棄物最終処分場浸出水 } \\
\text { の污染実態調査ならびに促進酸化による有機物およ } \\
\text { び色度除去法の検討 }\end{array}$ \\
\hline Author (s) & 石垣，智基; 立田，真文; Le，Van Chieu 他 \\
\hline Citation & 水環境学会誌. 25(11) p. 629-p. 634 \\
\hline Issue Date & 2002 \\
\hline oaire:version & VoR \\
\hline URL & https://hdl. handle. net/11094/3353 \\
\hline rights & \\
\hline Note & \\
\hline
\end{tabular}

Osaka University Knowledge Archive : OUKA

https://ir. Library. osaka-u. ac. jp/

Osaka University 


\title{
ベトナム・ハノイにおける廃棄物最終処分場浸出水の污染実態調査 ならびに促進酸化による有機物および色度除去法の検討
}

\author{
石 垣 智 基 ${ }^{*}$ 立田 真 文 $^{* *}$ Le Van Chieu ${ }^{* * *}$ Cao The Ha ${ }^{\dagger}$ Pham Hung Viet ${ }^{* * *}$ \\ 池道彦市藤 田 正 憲
}

Field Survey and Advanced Oxidation Treatment of Waste Landfill Leachate in Hanoi, Vietnam

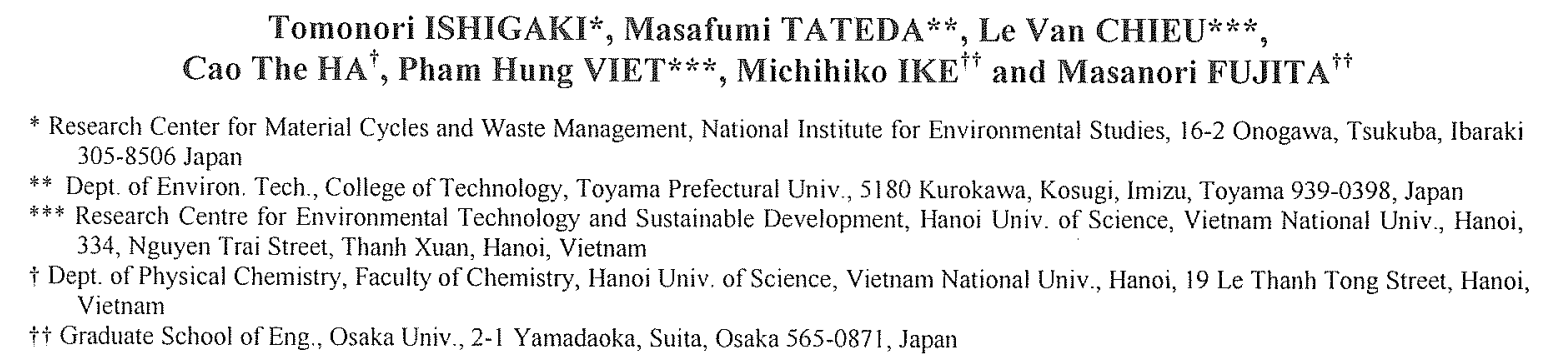

Abstract

The quality of leachate collected from waste landfills which received industrial and municipal waste in Hanoi was analyzed in order to obtain information on the current situation of pollutants in these sites. The leachate collected from Tay Mo landfill and Nam Son landfill showed the high concentration of iron and mercury. It was also recognized that the high strength of COD and color of leachate are the primary problems to be resolved at both sites. The application of several advanced oxidation processes (AOPs) to Tay Mo landfill leachate revealed that Fenton reaction and photo-Fenton reaction under $\mathrm{pH}$ adjustment effectively removed $\mathrm{COD}$ and color from the leachate and degraded the humic substance in it. Mutagenicity of the leachate was increased by UV- $\mathrm{TiO}_{2}-\mathrm{H}_{2} \mathrm{O}_{2}$, Fenton (pH 3) and UV-Fenton (pH 3) treatments. This indicates that degradation of organic matters in the leachate resulted in the generation of toxic intermediates. Further investigation of the operating conditions of AOPS is necessary to minimize the environmental impact of waste landfill leachate.

Key words: environmental problem in developing countries, Vietnam, waste landfill leachate, advanced oxidation

\section{1.はじめに}

地球温暖化やオゾン層の破懐など地球規模の環境問題 に対して耳目が集まる一方で，発展途上国に戈ける地域 的環境問題も早急に解決すべき問題として注目を集めて いる。途上国が経済成長括よび生活改善它成し遂げつつ環 境污染を最小限にくい止めるために泩, 環境破壊を代償 にして発展老遂げてきた先進国の果たすべき責任は大き い。また途上国に対して相当の環境保全対策を強いること は，単に当該国の経済成長を妨げるだけでなく，かつての ような先進国主導の成長路線が望めない現状においては 地球規模の持続的な棂展の障害となることも避けられな い。こうしたこと起踏まえた上で，我が国に拟ても途上
国に出ける環境問題の解決に向けての対策に貢献してい くことが求められている。

東南アジアの途上国であるべトナム社会主義共和国（以 下ベトナム）は, 社会経済の発展がめざましく,かつて新 興工業国・地域として飛躍的な成長をとげた台湾，あるい はシンガポールなどに続く新たな成長国家として期待が 奇せられている。一方で急激な工業化が深刻な環境污染を 引き起こして㧍り, 廃呆物処分に関わる環境污染もその 一つとして問題視されている。廃葉物埋立て処分場加ら発 生する浸出水が引き起こす水環境污染の危険性は世界的 に問題視されているりが, ベトナムにおける処分場浸出 水のモ二タリングデー夕は不足しており，その污染状況 が正確に把握できていないのが現状である。処分場浸出水

\footnotetext{
*国立環境研究所循環型社会形成推進・廃率物研究センター

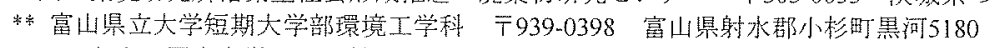

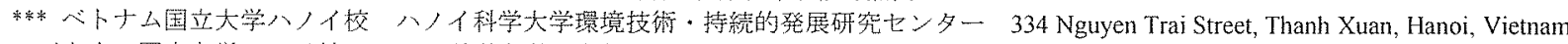

†ヘトナム国立大学ハノイ校 ハノイ科学大学化学部物理化学科 19 Le Thanh Tong Street, Hanoi, Vietnam

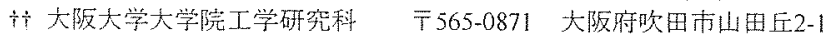


中の污染物質の濃度や種類は，処分場に埋め立てられた 廃菓物，処分場の構造，および気象条件に大きく依存吋万 ため，その実態解明なしには包括的な対策はたてられな い。また今後, 浸出水処理施設を導入していく上で, その 設計支援として水質モニタリングデータの蓄積は重要な 役割を果たす。以上のことから本研究では，べトナムの首 都である八ノイ市内に打忖生活系廃呆物処分プロセ又 の現状についてまとめるとともに，廃寨物理立て処分場 から発生する浸出水の水質モニタリングを行い，乙の污 染状況の把握および環境污染ポテンシャルの評俩を行つ た。また浸出水処理プロセスとして促進酸化法を提案し， 実浸出水老用いた各種の促進酸化法による処理性能の評 洒圭行った。

\section{2. 実験材料および方法}

\section{1 廃寨物処分場の概要および試料の採取}

八ノイ市の廃寨物埋立て処分場として，既に埋立てが 終了した市街地の南西約 $10 \mathrm{~km}$ に位置するTay Mo処分場, および現在理立て中で市街地から北方約 $50 \mathrm{~km}$ に位置する Nam Son処分場を調查の詨累とした。Tay Mo処分場は水田 地帯の一画に位置するオープンダンピング型の処分場で あり(Fig. 1)，周辺住民の苦情で廃妄物の投葉が中止され た半年後に試料を採取した。水試料処分場浸出水の湧出 口2力所 (浸出水試料 TM1, TM2), および浸出水が流入す るNhue川の流入口から抢々そ50m下流(TM3)から採取し， 分析に供した。Nam Son処分場㤌表面熫水工および集水管 の設置された処分場であり2，試料採取時において埋立開 始後約 1 年半が経過し, 計画埋立て量の約 3 分の1が完了し たところであった(Fig. 2)。浸出水試料(NS1)を浸出水出口 で採取守るとともに，浸出水放流先の河川水(NS2)お上び 周辺湖沼の表層水(NS3)採取し, 分析预上び促進酸化法 による処理に供した。

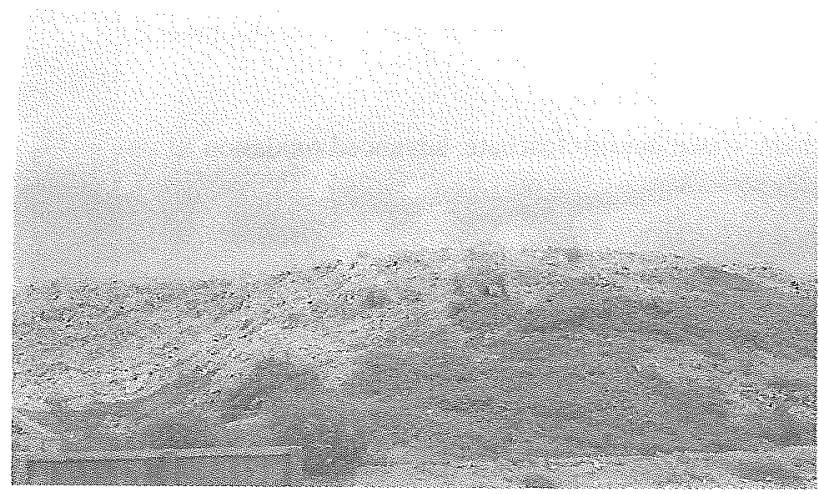

Fig. 1 Tay Mo waste landfill site

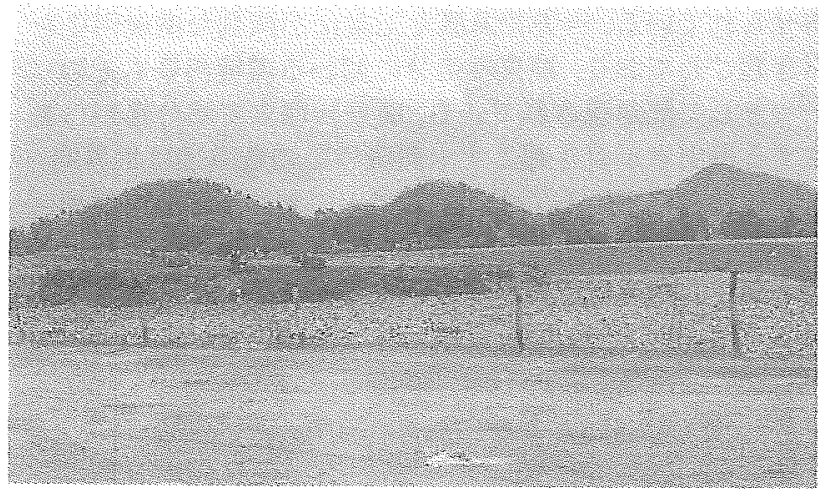

Fig. 2 Nam Son waste landfill site

\section{2 実験装置および促進酸化法の条件}

促進酸化反心装置の概要索Fig. 3に示す。実容積210二 重円筒形反応容器老用い, 外側の反店容器中にグラスフ アイバー濾紙で濾過した浸出水を循環させた。紫外線(UV) を用いる処理においては，内側の区応容器中にUVランプ (250W) 設置した。光触蝶としては, イルメナイト $\left(\mathrm{FeTiO}_{3}\right)$ 党活性炭上に吸着・焼結させたもの老用いた。促 進酸化法としては, 光触媒一紫外線照射 $\left(\mathrm{UV}-\mathrm{TiO}_{2}\right)$, 光触

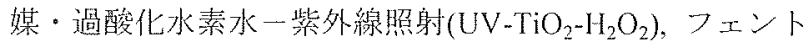


一紫外線照射（UVーフェントン酸化：pH来調整および


の下部老メッシュで力バ一し，专の内部に光触媒老 1.0 $\mathrm{g} \cdot \mathrm{l}^{-1}$ となるよう添加し紫外線照射壳行った。UV-TiO $\mathrm{T}_{2}-\mathrm{H}_{2} \mathrm{O}_{2}$ プロセスでは, $50 \%$ 過酸化水素水を $2.5 \mathrm{ml}^{-1}$ となるよう添 加した㖟，UV-TiO 2 プロセスと同様の操作を行った。つエ ントン酸化における鉄(II)イオンとしては, バトナム国内 で採掘される天然鉣物であるモール塩 $\left(\left(\mathrm{NH}_{4}\right)_{2} \mathrm{Fe}\left(\mathrm{SO}_{4}\right)_{2}\right.$ 。 $\left.6 \mathrm{H}_{2} \mathrm{O}\right)$ を用いた。モール塩を初期溃度が $2.5 \times 10^{-3} \mathrm{M}$ となる よう添加した後, $50 \%$ 渦酸化水素水党 $2.5 \mathrm{~m} / \mathrm{l}^{-1}$ となるよう 添加与るとともにフェントン酸化反応孝開始した。 $\mathrm{pH}$ 調 節は硫酸の添加により行った。UVーフェントン酸化ではつ エントン酸化と同様の操作の後, 紫外線照射を行って運 転定開始した。

\section{3 凝集海殿処理}

未処理の浸出水, ならびにUV-TiO $2, U V-\mathrm{TiO}_{2}-\mathrm{H}_{2} \mathrm{O}_{2}$, フ エントン酸化 ( $\mathrm{pH}$ 本調整) およびUV-フェントン酸化 $(\mathrm{pH}$ 末調整）の処理水について，モ一ル塩による凝集沈殿処理 を行った。試料水のpH住7.8-8.1であり，鉄塩による凝集沈 殿の至適 $\mathrm{pH}^{16)}$ にほぼ適合していると判断し，特段のpH調 整は行わなかった。凝集剂としてモ一儿塩支初期濃度名 $2.5 \times 10^{-3} \mathrm{M}$ となるよう添加し, 30分静置㖟の上澄み回収 して分析に供した。

\section{4 水質分析}

水質分析はJIS規格K0102に基づいて行った ${ }^{3)}$ 。浸出水の 化学的酸素要求量 (COD) は重ク口ム酸カリウム法によ り分析した。色度は波長 $390 \mathrm{~nm}$ の吸光度により測定した。 重金属類濃度时, 原子吸光光度計AA6800 (島津製作所社 製)により測定した。浸出水中のフミン質の分子量分布は, Sephadex G-50 (Pharmacia LKB., Uppsala, Sweden)によるゲ ル濾過クロマトグラフィー $(10 \mathrm{~cm}$ 径x $75 \mathrm{~cm}$ 屒力ラム, 展 開浴媒:50 mMリン酸バッファー $(\mathrm{pH} 7.0)$, 流速 $1.5 \mathrm{ml}$ $\mathrm{min}^{-1}$ ) による分画および波長 $390 \mathrm{~nm}$ の吸光度測定により 測定した。

\section{5 バイオアッセイ}

浸出水の变暴原性試験としてumu test ${ }^{4}$ 在適月した。供 試菌株としてはSalmonella thphymurium TA1535/pSK1002 株を用い，浸出水への暴露時間は2時間执よび4時間とし た。 $\beta$-ガラタトシダーゼ活性測定用基質としては2-二トロ フェニルー $\beta$-D-ガラタトピラノシドを用いた。陰性対象しし て滅菌水孝用い, 浸出水の防ガラタシダ一ゼ活性が用量 反店曲線老示し，ふつ陰性対象の活性の2倍以上を示した 場合に変異原性陽性と判定した。また, 浸出水のエストロ ゲン性試験よして醉母Two-Hybrid法 "5)適用し, 浸出水 への暴露時間は4時閒としてアッセイを行った。ßーガラク トシダーゼ活性測定は上記の条件に淮じた。 


\section{3. 家庭系廢栾物回収および好分の晲状}

Table 1にハノイに扔ける生活系廃寨物に関卞る統計 ${ }^{21}$ を示した。ベトナムとほぼ同じ面積の国土，および人口を 有する東南アジアの国の首都としてフィリピンのマニラ゙, およびほぼ同じ人口を有する日本の都市として大阪の統 計7も比較して示している。ベトナムの一人あたり GDPは 340米ドル(1997)であり ${ }^{8)}$ ，日本の37556米ドル(1998) ${ }^{9}$ はも ちろん,フィリピンの912米ドル $(1998)^{10)}$ にも及ばない。一 方，八イイおける一人あたりの家庭ゴミ発生量はマ二 ラの3倍にも達しており，大阪よりは少ないものの，日本 の全国平均とほぼ同程度であった ${ }^{11)}$ 。すなわらハノイお いては，政治体制扰よびライフスタイルを反映して，その 経済レベルに比較して廃寨物が発生しやすい社会構造と なっていることが推測される。

八ノイで発生する生活系廃菻物はUrban Environment Company (URENCO)という業者によって一括して回収お よび処分されており，乙の回収率は76\%にのぼっている。 生活采廃莱物の収集は每夕行われているが，狭い路地驾 多いため大型の集積車の通行が图難であることから，各 家庭の廃槨物は荷台付きの手押し台車を用いて手作業で 回収される (Fig.4)。作業員が各家庭より個別に運び出 される屋芥や路上の廃寨物を回収しながら，道幅の広い 幹線道路で待機している大型集積車まで運搬され埋立て 処分場一と搬送される。搬送先の埋立て処分場としては 2000年初頭まではTay Mo処分場が主であった。この処分 場は1997年よりURENCOにより管理されてきたが, 2000年 初頭に閉鎖された後は，市街地から北方 $50 \mathrm{~km}$ に位置する Nam Son処分場まで運搬され埋立てられている。長距離輸 送に加え，交通集中にともなう慢性的渋滞により，廃寨物 の収集および連搬に長時間を要していることが大きな問 題点として挙げられる。このように，経済成長およびそれ に伴う廃穣物発生量の增加に対し，廃衰物の回収・処分シ ステムが依然旧式のままで，整備が追いついていないの が現状であり，廃革物処分システムの高度化を踏まえた 収集運搬作業の簡素化が求められる。

Table 1 Comparison of statistics on waste among Hanoi, Manila and Osaka

\begin{tabular}{ccccc}
\hline & $\begin{array}{c}\text { Collection of } \\
\text { MSW }\end{array}$ & $\begin{array}{c}\text { Generation } \\
\text { of MSW }\end{array}$ & $\begin{array}{c}\text { MSW generation Recovery } \\
\text { per capita }\end{array}$ \\
\hline Hanoi & $1017 \mathrm{t}^{\circ} \mathrm{d}^{-1}$ & $1344 \mathrm{t}^{\circ} \mathrm{d}^{-1}$ & $1.02 \mathrm{~kg}^{\circ} \mathrm{d}^{-1}$ & $76 \%$ \\
Manila & $2633 \mathrm{t}^{\circ} \mathrm{d}^{-1}$ & $4052 \mathrm{t}^{\circ} \mathrm{d}^{-1}$ & $0.39 \mathrm{~kg}^{-1} \mathrm{~d}^{-1}$ & $65 \%$ \\
Osaka & $4664 \mathrm{t}^{\circ} \mathrm{d}^{-1}$ & $4906 \mathrm{t}^{\circ} \mathrm{d}^{-1}$ & $1.88 \mathrm{~kg}^{-1} \mathrm{~d}^{-1}$ & $95 \%$ \\
\hline
\end{tabular}

MSW: municipal solid waste



Fig. 4 Collection of municipal waste

\section{4. 实験結果および考察}

\section{1 処分場浸出水の水質分析}

Tay Mo処分場およびNam Son処分場より採取した浸 出水および周辺水環境中の重金属, COD漂度および色度を Table 2に示した。またTable 2には，べトナムの産業排水基 準および表層水水質基準も同時に示した。Tay Mo 処分場 浸出水試料TM1およびTM2は，高いCODおよびSS浱度を 示したほか，色度（主にフミン質）を示すA390が高い数值 を示した。TM1，TM2，ならびに河川水試料TM3において， 基準值を超えて検出された重金属類はTM3の水銀および 鉄の外で崩った。試料採取時においてTay Mo処分場浸出 水には高濃度の重金属類は含まれていないが，周辺水環 境では浸出水由来の重金属污染が進行している可能性が 獎念された。またNam Son 処分場浸出水試料NS1，および 周辺水環境試料NS2およびNS3は，いずれも高いCOD，水 銀および鉄浱度を示した。また, NS1は特に高い色度を示 した。廃㲤物中無機成分の洗い出しに影響を与える因子の 一つとして, 廃裹物層の梁さが挙げられている ${ }^{12)}$ 。Nam Son処分場は埋立てが進行中であり，廃案物層が低く，洗 い出し效果を受けやすかったことから, Tay Mo処分場に 比べて浸出水に高濃度の重金属が検出されたと推測され る。特にNS1中の水銀浱度は産業排水基準を上回っていた が, NS2およひNS3においても高濃度で水銀が検出されて おり，継続的なモニタリングによる十分な警戒が必要で あると言える。一方，生活系廃寨物が直接埋め立てられて いる処分場の浸出水では，埋立て終了後長期にわたり高 い有機物濃度が続くことが報告されている泫。これは嫌気 的条件下に扔いては，きわめて緩慢に固形廃萧物が分解 され，浸出水中に継続的に物質が溶解すること，および不 飽和透水係数の違いにより長く緩やかな浸透が起こりや すいこと胡な゙が原因として考えらてれる。いずれにして も Tay Mo処分場, およUNam Son処分場浸出水中から高 濃度のCODや高い色度が検出されていることは，浸出水 由来の污染が長期化する可能性老示唆しており，浸出水 処理㧍よび周辺環境污染防止策について検討することの 必要性が確認されたものといえる。特にTay Mo処分場は 市街地に近く，周辺環境污染の危険度も高いこと，および 遮水工構造を有していないことなどから, 浸出水を適切 に回収しその処理を行うことが強く求められる。そこで, 以降Tay Mo処分場浸出水を対象に，長期的な稓点から第 一に対策が必要であると考えられるCODおよび色度の除 去技術に関する検討を行った。

\section{2 促進酸化法による浸出水のCODおよび色度除去}

Fig. 5およびFig. 6に，各種促進酸化処理による処分場浸 出水中のCODおよび色度の除去について示した。CODお よび色度の除去に対しては何れも，フェントン酸化 $(\mathrm{pH}=3)$ およびUV-フェントン酸化 $(\mathrm{pH}=3)$ 方効果的であ り, CODについては $75 \%$ 前後, 色度については $85 \%$ 程度の 除去率が達成された。一般にUVーフェントン酸化は，フェ ントン酸化に比ベラジカルの発生量が多く, 酸化力も強 いとされている ${ }^{15}$ が, 浸出水のCODおよび色度除去にお いては，雨法でほぼ同程度の効果しか得られなかった。こ れは，高い色度によって紫外線が反忘槽内の浸出水に十 分に透過せず, 効率的なラジカルの発生が起こらなかっ たためと推測される。従って, 高い色度を有する浸出水に 
Table 2 Quality of leachate and surface water taken from Tay Mo and Nam Son waste landfill area. Vietnamese standards for surface water and industrial water were also shown.

\begin{tabular}{|c|c|c|c|c|c|c|c|c|c|c|c|c|}
\hline & & $\mathrm{Ni}$ & $\mathrm{Cu}$ & $\mathrm{Cd}$ & $\mathrm{Pb}$ & As & $\mathrm{Hg}$ & $\mathrm{Mn}$ & $\mathrm{Fe}$ & SS & COD & $\mathrm{A} 390$ \\
\hline \multirow{3}{*}{ leachate } & TM1 & 53 & 5.0 & 5.0 & 320 & 42 & 1.8 & 15 & 7500 & 280 & 920 & 3.1 \\
\hline & TM2 & 33 & 3.3 & 3.1 & 150 & 35 & 2.3 & 11 & 3250 & 790 & 725 & 3.0 \\
\hline & NS1 & 50 & 29 & 4.0 & 100 & 53 & 82 & 2200 & 10400 & 0.16 & 1010 & 2.3 \\
\hline \multirow{3}{*}{ surface water } & TM3 & 7.8 & 22 & 1.4 & 92 & 17 & 3.6 & 60 & 9610 & 170 & 43.4 & 0.15 \\
\hline & NS2 & 13 & 8.8 & 2.0 & 27 & 37 & 420 & 3200 & 18400 & 0.14 & 536 & 0.83 \\
\hline & NS3 & 12 & 31 & 2.0 & 21 & 31 & 60 & ND & 14100 & 0.22 & 150 & 0.29 \\
\hline \multirow{2}{*}{\multicolumn{2}{|c|}{$\begin{array}{l}\text { VN standard for surface water } \\
\text { VN standard for industrial water }\end{array}$}} & 1000 & 1000 & 20 & 100 & 100 & 2 & 800 & 2000 & 80 & 35 & - \\
\hline & & 2000 & 5000 & 500 & 1000 & 500 & 5 & 5000 & 10000 & 200 & 400 & - \\
\hline
\end{tabular}

Unit: Metals; $\mu \mathrm{g} \cdot l^{-1}, \mathrm{SS}$ and COD; $\mathrm{mg} \cdot l^{-1}$

対して,UV照射を含む促進酸化プロセスを適用する際に は，その照射方法について十分検討することが必要であ り，同程度の処理性能しか得られないのであれば，責用や 運転管理など実用的な観点からいって, UV照射は不要で あることが提案されよう。Fig.7には浸出水拉よび促進酸 化処理水中のフミン質の分子量分布を示した。溶出容量 60 $m l$ および $150 \mathrm{ml}$ 付近のピークはフェントン酸化 $(\mathrm{pH}=3)$ お よびUV-フェントン酸化 $(\mathrm{pH}=3)$ 処理によって減少してお り, 効率的な色度除去はフミン質の酸化分解に起因する ところが大さいと推测された。また新たなピークの出現は 見られなかったことから, 浸出水中のフミン質は促進酸 化処理により低分子化されるが，重合反応が生じ高分子

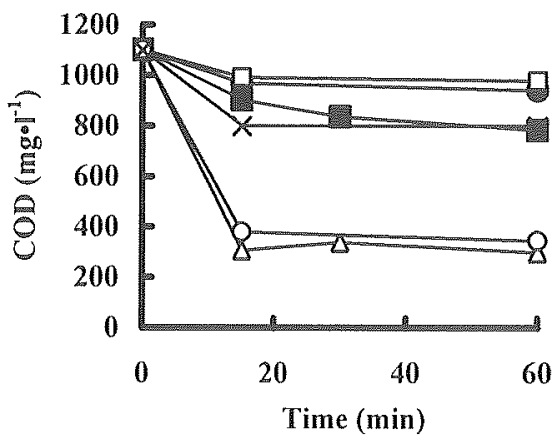

Fig. 5 COD removal from leachate by AOPs. $\square: U V-\mathrm{TiO}_{2}$, 0 : $\mathrm{UV}-\mathrm{TiO}_{2}-\mathrm{H}_{2} \mathrm{O}_{2}$,

圈:Fenton, $\triangle:$ Fenton (pH=3), $\times: U V-$ Fenton, $\mathrm{O}: \mathrm{UV}-$ Fenton $(\mathrm{pH}=3)$

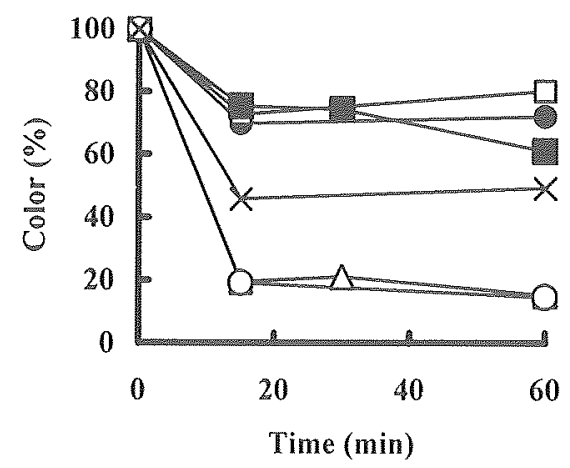

Fig. 6 Decolorization of leachate by AOPS. $\square: \mathrm{UV}-\mathrm{TiO}_{2}$, $\mathrm{UV}-\mathrm{TiO}_{2}-\mathrm{H}_{2} \mathrm{O}_{2}$,

龢:Fenton, $\triangle:$ Fenton $(\mathrm{pH}=3), \times: \mathrm{UV}-$ Fenton, $\mathrm{O}: \mathrm{UV}-\mathrm{Fenton}(\mathrm{pH}=3$ )
量の中間物質が生成されることはないものと考えられた。 効䜌的なCOD拉よび色度除去が確認されたフェントン 酸化 $(\mathrm{pH}=3)$ 扝よびUV-フェントン酸化 $(\mathrm{pH}=3)$ 以外の促 進酸化処理水に対し，凝集沈殿を適用した結果をTable 3 に示した。浸出水を直接凝集沈殿処理した場合には, COD が24.2\%，また色度は3.6\%しか除去されなかったのに対し て, UV-TiO $\mathrm{T}_{2}$ おびUV-TiO $\mathrm{O}_{2}-\mathrm{H}_{2} \mathrm{O}_{2}$ 処理後の浸出水では, 凝 集沈殿による色度の除去が大幅に促進された。このように， 凝集沈殿の性能充高的といら観点からも促進酸化処理 が有効であることが示された。一方で, $\mathrm{pH}$ を調節しなかっ たフェントン酸化および同じく $\mathrm{pH}$ 調節しなかったUVフェントン酸化では，ての後の凝集沈殿によってCOD除 去は促進されたが，色度は逆に増加した。雨プロセスにお いては, フェントン反灾の時点で鉄(II)イオンがすでに添 加されており, 凝集沈殿処理の際に過剩の鉄が添加され

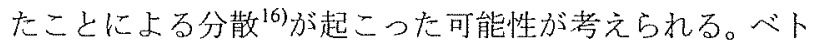
ナム国内においては産業用の薬凨についても必ずしも購 入は容易ではないが,フェントン酸化で用いられるモー 儿塩は国内で生産されて抢り，安定して供給されている。 また過酸化水素は中国から輸入されており，比較的安俩 (約500米ドル・五)で入手可能である。ここで, 現地で安定し て入手可能な薬剤を用いた効率的な処理技術が提案され たことは，今後の処理技術の普及において大きな利点と なるものと期待される。

Table 3 Removal of COD and color by combination of advanced oxidation treatment and coagulation

\begin{tabular}{|c|c|c|c|c|}
\hline & \multicolumn{2}{|c|}{$\mathrm{COD}$} & \multicolumn{2}{|c|}{ A390 } \\
\hline & $\begin{array}{l}\text { Conc. } \\
\left(\mathrm{mg}^{*} \mathrm{l}^{-1}\right)\end{array}$ & $\begin{array}{c}\text { Removal } \\
(\%)\end{array}$ & Unit & $\begin{array}{c}\text { Removal } \\
(\%)\end{array}$ \\
\hline Raw leachate (R) & 1100 & - & 3.07 & - \\
\hline$R+$ coagulation $(C)$ & 833.8 & 24.2 & 2.96 & 3.6 \\
\hline $\mathrm{UV}-\mathrm{TiO}_{2}$ & 977.4 & 11.1 & 2.46 & 19.9 \\
\hline $\mathrm{UV}-\mathrm{TiO}_{2}+\mathrm{C}$ & 803.7 & 26.9 & 2.33 & 24.1 \\
\hline UV- $\mathrm{TiO}_{2}-\mathrm{H}_{2} \mathrm{O}_{2}$ & 940.6 & 14.5 & 2.21 & 28.0 \\
\hline $\mathrm{UV}-\mathrm{TiO}_{2}-\mathrm{H}_{2} \mathrm{O}_{2}+\mathrm{C}$ & 774.9 & 29.5 & 1.68 & 45.3 \\
\hline Fenton & 783.4 & 28.8 & 1.87 & 39.1 \\
\hline Fenton $+\mathrm{C}$ & 694.4 & 36.9 & 2.20 & 28.3 \\
\hline Fenton ( $\mathrm{pH}=3$ ) & 297.9 & 72.9 & 0.464 & 84.9 \\
\hline UV-Fenton & 799.5 & 27.3 & 1.51 & 50.7 \\
\hline UV-Fenton $+\mathrm{C}$ & 677.9 & 38.4 & 2.40 & 21.8 \\
\hline UV-Fenton $(\mathrm{pH}=3)$ & 344.0 & 68.7 & 0.446 & 85.5 \\
\hline
\end{tabular}






Fig. 7 Distribution of molecular weight of humic substances in leachate.

:raw leachate, $\square: \mathrm{UV}-\mathrm{TiO}_{2}$, $: \mathrm{UV}-\mathrm{TiO}_{2}-\mathrm{H}_{2} \mathrm{O}_{2}$, 圈:Fenton,

$\triangle:$ Fenton ( $\mathrm{pH}=3), \times: U V-F e n t o n, O: U V-F e n t o n(\mathrm{pH}=3)$

4.3 バイオアッセイによる各规理法の評価1

Fig. 8にumu testの結果得られた浸出水および各処理水 の用量反応曲線を示した。浸出水からは変異原性は検出さ れなかったのに対して、フェントン酸化 $(\mathrm{pH}=3), \mathrm{UV}$ ーフェ ントン酸化 $(\mathrm{pH}=3)$, 括上びUV $-\mathrm{TiO}_{2}-\mathrm{H}_{2} \mathrm{O}_{2}$ 処理水からは変 異原性が検出された。また，エストロゲン性はす心゙ての試 料から検出されなかった（データ不載）。今回採用された 試験方法は一次スクリーニング手法であること，より高 い濃度域での試験ができなかったことなどから、これら の試料の毒性について正確な評価が行われたとはいいき れないが, 上記の3種の促進酸化処理により浸出水の变異 原性が高くなる可能性が示されたことは確かである。有機 物の促進酸化処理による非意図的な毒性物質の生成，お よび蓄積についてはこれまでにも報告されており ${ }^{17)}$, 不完 全な酸化反応による中間生成物の残存が主な原因上考え られている。すなわち，添加物質の量や反灾時間など適切 な反忘条件老設定し，二れらの中閒生成物質を完全に分 解することが，浸出水の促進酸化処理を実用化するうえ で重要な課題である。また途上国に抽ても，一次スクリ 一ニング的なバイオアッセイ老浸出水評価へ適用し, 集 中的に毒性モニタリングを行っていくことが，総合的な 処理性能評洒，ひいては水環境全体に与える影響の評洒 定行ううえで有効と考えられる。



Fig. 8 Dose-response curve of mutagenicity of leachate. : Raw leachate, and $\square: \mathrm{UV}-\mathrm{TiO}_{2}$, UV-

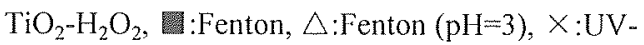

Fenton and $\mathrm{O}: \mathrm{UV}-\mathrm{Fenton}(\mathrm{pH}=3)$ treated leachate.

\section{5. まとめ}

八ノイ市内に执いて発生する廃亜物の最終処分場, お
よびすでに閉鎖された处分場から発生する浸出水の水質 調查を行った結果，高いCODおよび色度を有すること，お よび様々な重金属の污染源となっていることが明らかと なった。こうした高いCODや色度を有する廃衰物玑分場浸 出水の処理技術として期待される, 各種促進酸化法を用 いて実浸出水の処理性能を比較した結果, 浸出水の $\mathrm{pH}$ 的 に調節しフェントン酸化执よびUVーフェントン酸化を適 用することがCODおよび色度の除去に対して効率的であ ることが明らかとなった。また, 凝集沈殿処理単独では CODおよび色度は十分に除去されないが, UV-TiO 2 および $\mathrm{UV}-\mathrm{TiO}_{2}-\mathrm{H}_{2} \mathrm{O}_{2}$ プロセスとの組合せにより，特に色度の除 去が促進されることが示された。これらの処理に用いられ るモ一儿塩および過酸化水素は八ノイ市内においても比 較的入手が容易な薬郕であり，地域の特性にも適合した 処理技術しして期待される。また浸出水からは変異原性が 唡出されなかったのに対してフェントン酸化 $(\mathrm{pH}=3)$, UVーフエントン酸化 $(\mathrm{pH}=3)$, 扝よびUV-TiO $\mathrm{T}_{2}-\mathrm{H}_{2} \mathrm{O}_{2}$ 処理水 からは変異原性が検出され，簡易毒性モニタリングによ る処分場浸出水管理の有効性が示された。地球規模での持 続的成長を見据え, 発展途上国の環境問題解決に対する 貢献はますます重要となるものと考えられる。バイオアッ セイによる水質評価など最新の技術導入に加えて, 地域 性索考慮した処理技術の検討は, 将来的な問題解決の上 で必要不可欠であるといえよう。今後も先進国が果たす心゙ き重要な役割として, 現地の状況に適态した環境技術支 援を続けることが期待される。 謝辞

本研究は日本学術振與会東南アジア諸国学術交流事羓 起点大学方式交流における共同研究の一部として行われ た。ここに記して謝意を表する。

（原稿受付 2002年6月27日）

(原稿受理 2002年8月14日)

\section{參岩 文 献}

1) Christensen, J. B. and Christensen, T. H. (2000) The effect of pH on the complexation of $\mathrm{Cd}, \mathrm{Ni}$ and $\mathrm{Zn}$ by dissolved organic carbon from leachate-polluted groundwater, Wat. Res., 34, 3743-3754.

2) Japan International Cooperation Agency and Hanoi People's Committee (1999) Socialist Republic of Vietnam The Study on Environmental Improvement for Hanoi City in the Socialist Republic of Vietnam Interim Report Volume 3.

3) Japanese Standard Association (1995) Japanese Industrial Standard K102, Japanese Standard Association, Tokyo, Japan, 134-145.

4) Oda, Y., Nakamura, S., Shimada, T., Oki, I. and Shinagawa, H. (1985) 
Evaluation of the new system (umu test) for the detection of environmental mutagens and carcinogens, Mutation Res., 147, 219-229.

5) Nishikawa, J., Saito, K., Goto, J., Dakeyama, F., Matsui, M. and Nishihara, T. (1999) New screening methods for chemicals with hormonal activities using interaction of nuclear hormone receptor with coactivator, Toxicol. Appl. Pharmacol., 154, 76-83.

6) 小椋硉二 (2000) マニラ首都圈の家庭ゴミの㚾分状況，用水と廃水， 42, 1123-1128.

7) 大汳书 (2002) 第89回大阪市統諳書平成13年度版

8) Hanoi Statistical Office (1998) 1997 Hanoi Statistics Yearbook, Hanoi Urban Master Plan for 2020

9) 内閣府経济社会総合研究所 (2001) 平成12年度国民経済計算年報 確報

10) 外務省 (2001) 各国・拈域情勢

http://www.mofa.go.jp/mofaj/area/philippines/index.html

11）廃亲物情報研究会編（2001）Fact Book 廃案物基本デー夕集2000,
日本環境衛生センター, 川槣

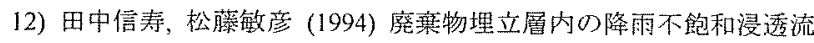
れによる非反応性物質輸送（混合）現象への执散モデルや二成分 モデルの適用性, 廃率物学会論文誌, 5, 1-10.

13) Palmisano, A.C. and Barlaz, M.A. Ed. (1996) Microbiology for solid waste, CRC Press, Inc, Boca Raton, Florida.

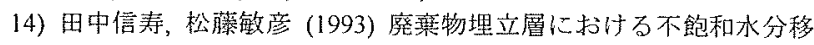
彭特性とその測定法に関与万研究, 廃集物学会論文誌, 4, 107-115

15) Pignatello, J. J. (1992) Dark and photoassisted $\mathrm{Fe}^{3+}$ - catalyzed degradation of chlorophenoxy herbicides by hydrogen peroxide, Environ. Sci. Tech, 26, 944-951.

16) 松星友矩 監訳 (1993) 水翼環境工学, 技報堂, 東京

17) Manilal, V. B., Haridas, A., Alexander, R. and Surender, G.D. (1992) Photocatalytic treatment of toxic organics in wastewater: Toxicity of photodegradation products, Wat. Res., 26, 1035-1038. 